\title{
Communication
}

[Comunicação]

\section{Detection of antimicrobial and anthelmintic residues in bulk tank milk from four different mesoregions of Minas Gerais State - Brazil}

\author{
[Detecção de resíduos antimicrobianos e anti-helmínticos no leite de tanque de quatro mesorregiões \\ do estado de Minas Gerais - Brasil] \\ M.M.O.P. Cerqueira ${ }^{1}$, F.N. Souza ${ }^{1}$, A.F. Cunha ${ }^{1}$, L.C.A. Picinin ${ }^{2}$, M.O. Leite ${ }^{1}$, \\ C.F.A.M. Penna ${ }^{1}$, M.R. Souza ${ }^{1}$, L.M. Fonseca ${ }^{1}$ \\ ${ }^{1}$ Escola de Veterinária - Universidade Federal de Minas Gerais - Belo Horizonte, MG \\ ${ }^{2}$ Universidade Federal de Santa Catarina - Florianópolis, MG
}

\begin{abstract}
Milk is one of the most consumed foods worldwide and its production has shown a continuous increase (Oliveira et al., 2010). Brazil is one of the largest producers and consumers of cow milk in the world, with about 30.7 billion liters of milk produced in 2010. Minas Gerais State is the major milk producer in Brazil, and it is responsible for approximately $30 \%$ of the national milk production. The Central Mineira, Oeste of Minas, Triângulo Mineira/Alto Paranaíba and Metropolitana de Belo Horizonte mesoregions are important milk producing regions in Minas Gerais State, Brazil, with a settlement of several important dairy industries (Figure 1). Raw milk collected in these regions supplies dairies with cheese, dry milk, yogurt, milk beverages, dessert cream, pasteurized and UHT milk production (Borges et al., 2013).
\end{abstract}

Antimicrobial and anthelmintic drugs are widely used in veterinary medicine and the residues of these drugs constitute a risk for human health since they can cause allergic reactions in hypersensitive individuals and may lead to the appearance of drugresistant bacteria, nematodes or trematodes. Thus, analysis of these residues plays a key role in ensuring food safety, and to accomplish this objective, maximum residue levels for these drugs have been established by regulatory agencies in many countries, including Brazil (Brazil, 1999). Failure to observe stipulated withdrawal periods for these drugs has resulted in several reports of their residues in milk. However, few data are available in Brazil, mainly when considering the anthelmintic drugs (Lobato et al., 2006; Nero et al., 2007; Bando et al., 2009; Fonseca et al., 2009; Oliveira et al., 2010; Zanella et al., 2010).

Recebido em 30 de setembro de 2013

Aceito em 17 de fevereiro de 2014

E-mail: monicamopc@ufmg.br
Thus, the present study aimed to evaluate the residues of antimicrobial and anthelmintic drugs in bulk tank milk samples from four different mesoregions of Minas Gerais State, Brazil. For the present study 83 bulk tank milk samples were collected for anthelmintic residue detection from four different mesoregions (22 cities) of Minas Gerais State (Triângulo Mineiro/Alto Paranaíba, $\mathrm{n}=37$; Oeste de Minas, $\mathrm{n}=26$; Central Mineira, $\mathrm{n}=15$; and Metropolitana de Belo Horizonte, $n=5$ ) during January, 2012 (Fig. 1a), which represent the most important dairy regions of Minas Gerais State, and those 70 milk samples were also analyzed for antimicrobial residues. The antimicrobial residue detection included quinolones, ceftiofur, thiamphenicol, streptomycin, tylosin and tetracyclines, while antithelmintics detected included benzimidazoles, amino benzimidazoles, levamisole, avermectins, thiabendazole, moxidectin and triclabendazole. The preparation of the milk samples, the detection of the antimicrobials (Anti Microbial Array II, cat $\mathrm{n}^{\circ}$. EV3524A; Randox Laboratories Ltd., UK) and of the anthelmintics (Anthelmintics Array, cat $\mathrm{n}^{\circ}$. EV3770; Randox Laboratories Ltd., UK) were performed with a biochip array platform, using competitive antibody-capture immunoassay as recommended by the manufacturer's protocol. The amino benzimidazoles assay included detection of amino-mebendazole, albendazole 2-amino sulphone, and amino-fluobendazole; the avermectins assay included emamectin benzoate, epinomectin, abamectin, ivermectin, and doramectin; the thiabendazole assay included detection of cambendazole, thiabendazole, and 5hydroxythiabendazole; and the triclabendazole assay included keto-triclabendazole, triabendazole, and triclabendazole sulphoxide. 


\section{Cerqueira et al.}

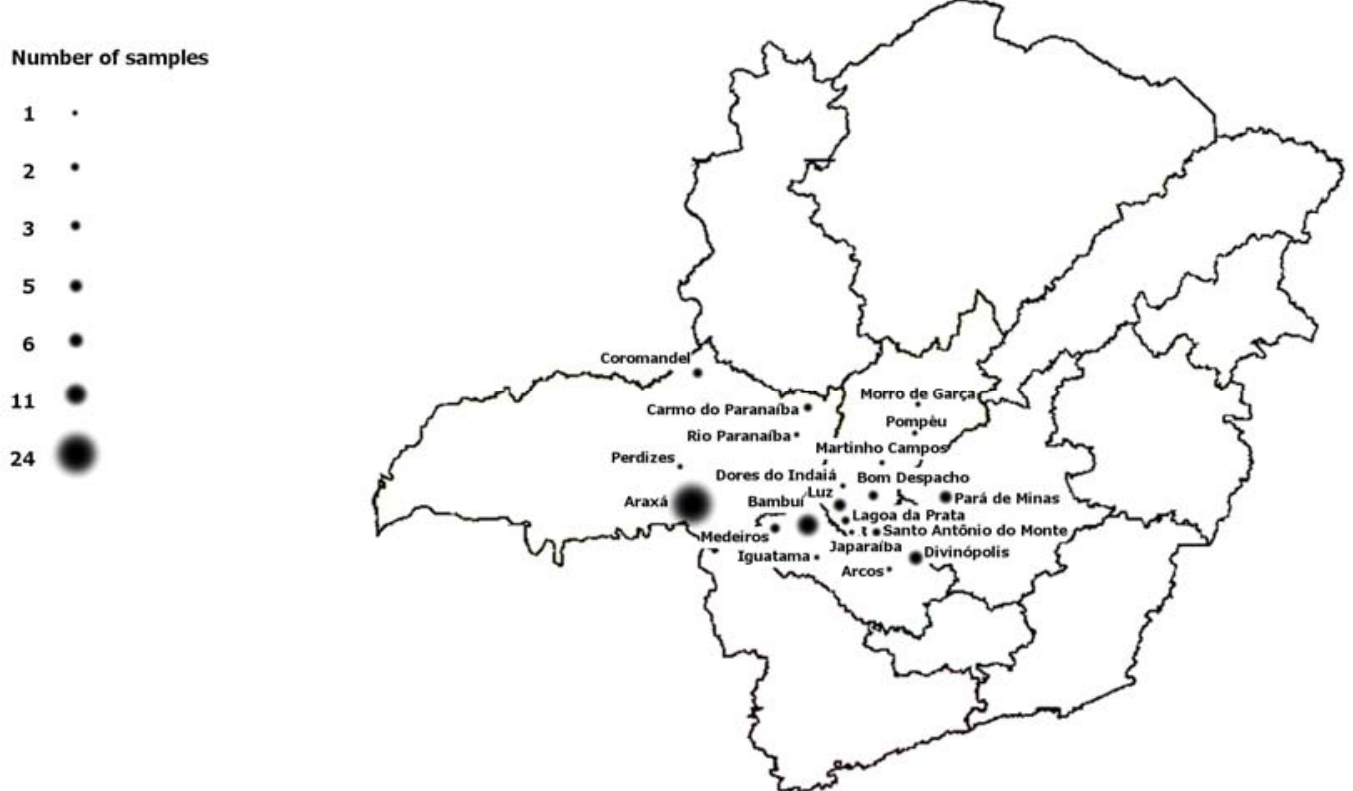

Figure 1. a) Geographical origin of raw milk samples submitted for anthelmintic and antimicrobial residue detection from four different mesoregions of Minas Gerais State - Brazil. b) Milk production from the different mesoregions of Minas Gerais State - Brazil in 2010.

The results are showed in Table 1, and were divided in: 1) samples between the limit level of detection of the kits and the Brazilian maximum residue levels (BMRLs) (quinolones $40 \mu \mathrm{g} / \mathrm{L}$; ceftiofur $100 \mu \mathrm{g} / \mathrm{L}$; thiamphenicol $50 \mu \mathrm{g} / \mathrm{L}$; streptomycin $200 \mu \mathrm{g} / \mathrm{L}$; tetracyclines $100 \mu \mathrm{g} / \mathrm{L}$; avermectins $10 \mu \mathrm{g} / \mathrm{L}$; and 2) samples with levels above the BMRLs.

Table 1. Detection of antimicrobials $(n=70)$ and anthelmintics $(n=83)$ residues in bulk tank milk samples from Minas Gerais State, Brazil

\begin{tabular}{|c|c|c|c|}
\hline & & $\begin{array}{l}\text { Number of samples } \\
\text { between the LLD } \\
\text { and BMRLs levels }\end{array}$ & $\begin{array}{c}\text { Number of } \\
\text { samples with } \\
\text { levels above the } \\
\text { BMRLs }\end{array}$ \\
\hline \multirow[t]{6}{*}{ Antimicrobials } & Quinolones & $2(2.86 \%)$ & $0(0 \%)$ \\
\hline & Ceftiofur & $0(0 \%)$ & $0(0 \%)$ \\
\hline & Thiamphenicol & $0(0 \%)$ & $0(0 \%)$ \\
\hline & Streptomycin & $2(2.86 \%)$ & $0(0 \%)$ \\
\hline & Tylosin & $0(0 \%)$ & - \\
\hline & Tetracyclines & $8(11.43 \%)$ & $0(0 \%)$ \\
\hline \multirow[t]{7}{*}{ Anthelmintics } & Benzimidazoles ${ }^{*}$ & $0(0.00 \%)$ & - \\
\hline & Amino Benzimidazoles & $0(0.00 \%)$ & $0(0 \%)$ \\
\hline & Levamisole $^{*}$ & $45(54.22 \%)$ & - \\
\hline & Avermectins & $50(60.24 \%)$ & $5(6.02 \%)$ \\
\hline & Thiabendazole* & $56(67.47 \%)$ & - \\
\hline & Moxidectin & $61(73.49 \%)$ & $0(0 \%)$ \\
\hline & Triclabendazole $^{*}$ & $38(45.78 \%)$ & - \\
\hline
\end{tabular}

*BMRLs not established for milk

LLD: limit level of detection

BMRLs: Brazilian maximum residue levels 
Although most of the drug residue concentrations were below the current BMRLs (Brazil, 1999), this survey indicates that the withdraw periods for antimicrobials, and especially for anthelmintic drugs has not been fully respected by all dairy farmers.

Reports have shown that some anthelmintics found in milk are stable during storage and are not affected by some fermentation processes. Sometimes even an increase in concentration may occur, as showed in ripened cheese (Whelan et al., 2010). Furthermore, since the use of anthelmintic drugs in lactating cows is prohibited in Brazil, these results demonstrate the need for more strict control of their use to ensure milk safety, quality, and integrity (Brazil, 2002).

Findings similar to the present study were reported by Nero et al. (2007), who found $11.0 \%$ of raw milk samples from four cities (Viçosa from Minas Gerais State; Pelotas from Rio Grande do Sul State; Londrina from Paraná State; and Botucatu from São Paulo State) with antimicrobial residues, and by Brazil (2011) which reported no milk samples above the BMRLs. A survey of antimicrobial residues in UHT milk and milk powder performed by the Program of Analysis of Veterinary Drugs Residues in Food from Animal Origin (ANVISA, 2009) in 12 States from Brazil also reported similar results, with no positive samples, in both UHT milk and milk powder, for ceftiofur, thiamphenicol and erythromycin (quinolones) residues. Positive samples for streptomycin and dihydrostreptomycin residues accounted for $3.66 \%$ and $3.60 \%$, in UHT milk and milk powder, respectively. Positive samples for tetracycline residues were $1.71 \%$, and $15.83 \%$ in UHT milk and milk powder, respectively. No positive sample for antimicrobial residues was above the BMRLs (ANVISA, 2009). Fonseca et al. (2009) also described $4.0 \%$ of positive samples for antimicrobial residues in UHT milk that were collected from retail establishments in the city of Rio de Janeiro. Conversely, these results are below those reported by Bando et al. (2009) in 35 cities of Paraná State from March 2005 to
April 2006, and Zanella et al. (2010) in the State of Paraná during January 2006 to June 2007 both in pasteurized milk, who found, respectively, $41.4 \%$ and $30.8 \%$ of milk samples with antimicrobial residues. On the other hand, the percentage of positive milk samples was higher than those results showed by Oliveira et al. (2010) who did not encounter any residues of streptomycin or dihydrostreptomycin in pasteurized bovine milk during May 2009 from five cities of São Paulo State. The differences in the percentage of positive samples for veterinary drug residues may also be related to geographical and seasonal factors.

It is noteworthy that the occurrence of anthelmintc residues reported in this work are slightly higher than those described by Brazil (2011) which described none of milk samples above the BMRLs (Table 1 and Figure 2). Lobato et al. (2006) also reported that $17.8 \%$ of the retailed milk samples contained ivermectin levels above the detection limit by highperformance liquid chromatography with fluorescence detector, but none of these samples had levels above the BMRLs. Therefore, the findings in the current report of anthelmintic residues in raw milk are similar to those described by the Program of Analysis of Veterinary Drugs Residues in Food from Animal Origin (ANVISA, 2009) for UHT milk and dry milk, respectively: $2.80 \%$, and $7.25 \%$ of positive samples for abamectin residue; $41.29 \%$ and $52.17 \%$ of positive samples for ivermectin residue; and $3.87 \%$ and $5.80 \%$ of positive samples for doramectin residue. One sample of UHT milk $(0.22 \%)$ presented doramectin levels above the BMRLs. All of these reported anthelmintics belong to the abamectins group.

Although fast screening methods (i.e. immunological or microbial inhibition assays) are commonly used to detect the presence of antimicrobial and anthelmintics in foods, more accurate chromatographic methods are required by the governmental regulatory agencies to identify and confirm the presence of these compounds (Oliveira et al., 2010). 


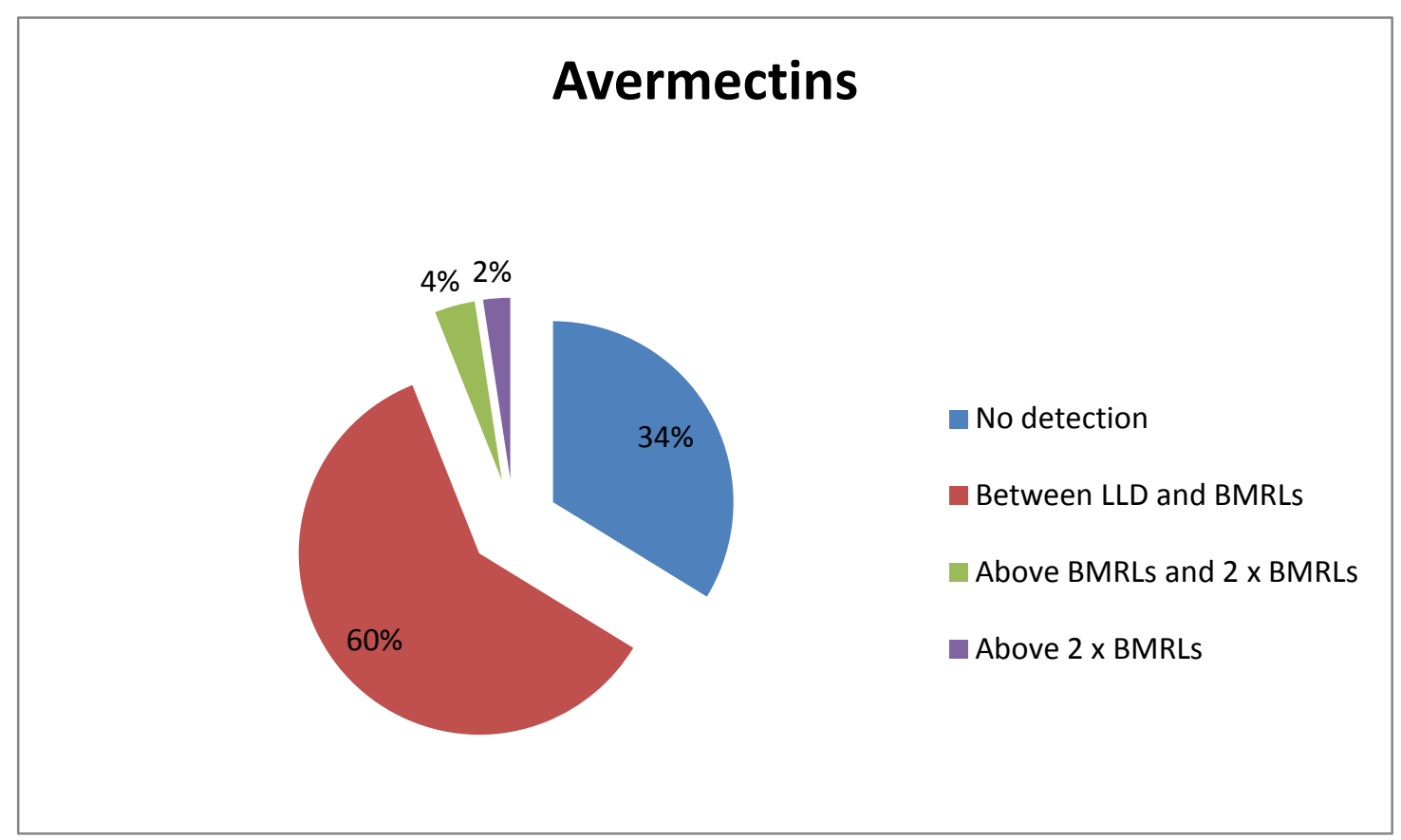

Figure 2. Percentage of milk samples between the limit level of detection (LLD) and the Brazilian maximum residue levels (BMRLs); samples between BMRLs and two fold of the BMRLs, and samples above two fold BMRLs for avermectins.

The findings of the present report indicate the need of a stricter monitoring of the veterinary drug residues in milk produced in Minas Gerais State. To reach this objective, continuous monitoring programs should be applied in order to offer a safer product to consumers. Additionally, more research should be carried out in several different regions of Minas Gerais State and other Brazilian states to obtain a more precise dimension of this risk to implement effective corrective actions.

Keywords: dairy cows, milk, MRLs,veterinary drugs

\section{RESUMO}

Avaliou-se a presença de resíduos antimicrobianos (ceftiofur, estreptomicinas, quinolonas, tetraciclinas, tianfenicol e tilosina) e anti-helmínticos (benzimidazóis, aminobenzimidazóis, levamisol, avermectinas, tiabendazóis, moxidectina e triclabendazóis) em, respectivamente, 70 e 83 amostras de leite cru provenientes de quatro mesorregiões (Triângulo Mineiro/Alto Paranaíba, Central Mineira, Oeste de Minas e Metropolitana de Belo Horizonte) do estado de Minas Gerais. Este estudo demonstrou a presença de quinolonas (2,86\%), estreptomicinas $(2,86 \%)$ e tetraciclinas $(11,43 \%)$ nas amostras de leite cru analisadas. Ademais, observou-se expressiva porcentagem de amostras de leite cru positivas para os anti-helmínticos amino- benzimidazóis (55,42\%), levamisol (53,57\%), avermectinas (60,24\%), tiabendazóis (67.47\%), moxidectina (73,49\%) e triclabendazóis (45,78\%), e em menor porcentagem os benzimidazóis (6,02\%). Desta forma, os resultados do presente estudo indicam que os resíduos de antimicrobianos e anti-helmínticos no leite em Minas Gerais devem ser constantemente monitorados pelas autoridades competentes com intuito de oferecer aos consumidores um alimento sem riscos à saúde humana.

Palavras-chave: bovinos leiteiros, leite, LMR, medicamentos veterinários 


\section{Detection of antimicrobial...}

\section{REFERENCES}

ANVISA - Agência Nacional de Vigilância Sanitária. Programa de análises de resíduos de medicamentos veterinários em alimentos de origem animal - PAMVet. Relatório 2006/2007 Monitoramento de Resíduos em leite exposto ao consumo $\left(5^{\circ} \mathrm{e} 6^{\circ}\right.$ anos de atividades), $76 \mathrm{p}$., 2009. Disponível em: <http://portal.anvisa.gov.br/ wps/wcm/connect/d7ab358047458ad19443d43fbc4c6 735/PAMVET.pdf?MOD=AJPERES $>$. Acessado em: 14 maio 2012.

BANDO, E.; OLIVEIRA, R.C.; FERREIRA, G.M.Z.; MACHINSKI JR., M. Occurence of antimicrobial residues in pasteurized milk commercialized in the state of Paraná, Brazil. $J$. Food Prot., v.72, p.911-914, 2009.

BRASIL. Ministério da Agricultura, Pecuária e Abastecimento. Instrução Normativa $N^{\circ} 42$ de 20 de dezembro de 1999. Plano Nacional de Controle de Resíduos em Produtos de Origem Animal - PNCR. Diário Oficial da União, Brasília, 22 de dezembro de 1999. Seção 1.

BRASIL. Ministério da Agricultura, Pecuária e Abastecimento. Instrução Normativa $N^{\circ} 51$ de 18 de setembro de 2002. Regulamento Técnico de Produção, Identidade e Qualidade do Leite tipo $A$, do leite tipo $B$, do leite tipo $C$, do leite pasteurizado e do leite cru refrigerado e o Regulamento Técnico da coleta de leite cru refrigerado e seu transporte a granel. Diário Oficial da União, Brasília, 18 de setembro de 2002. Anexo VI.

BRASIL. Ministério da Agricultura, Pecuária e Abastecimento. Instrução Normativa $\mathrm{N}^{\circ} 6$ de 25 fevereiro de 2011. Programas de Controle de Resíduos e Contaminantes dos subprogramas de monitoramento e exploratório em Carnes (Bovine, Suína, Aves e Equina), Leite, Ovos, Mel e Pescado do exercício de 2010. Diário Oficial da União, 25 de fevereiro de 2011.
BORGES, L.R.; FONSECA, L.M.; MARTINS, R.T.; OLIVEIRA, M.C.P.P. Milk quality according to the daily range in farm production in the Mesoregion Central Mineira and Oeste of Minas Gerais regions, Brazil. Arq. Bras. Med. Vet. Zootec., v.65, p.1239-1246, 2013.

FONSECA, A.P.; CRUZ, A.G.; FARIA, J.A.F. et al. Antibiotic residues in Brazilian UHT milk: screening study. Cienc. Tecnol. Aliment., v.29, p.451-453, 2009.

LOBATO, V.; RATH, S.; REVES, F.G.R. Occurence of ivermectin in bovine milk from the Brazilian retail market. Food Addit. Contam., v.23, p.668-673, 2006.

NERO, L.A.; MATTOS, M.R.; BELOTI, V. et al. Resíduos de antibióticos em leite cru de quatro regiões leiteiras no Brasil. Ciênc. Tecnol. Aliment., v.27, p.391-393, 2007.

OLIVEIRA, R.C.; PASCHOAL, J.A.R.; REYES, F.G.R. Streptomycin and dihydrostreptomycin residues on bovine milk from Brazilian retail market. Food Addit. Contam. B, v.3, p.156-162, 2010.

WHELAN, M.; CHIROLLO, C.; FUREY, A.L. et al. Investigation of the persistence of levamisole and oxyclozanide in milk and fate in cheese. J. Agric. Food Chem., v.58, p.1220412209, 2010.

ZANELLA, G.N.; MIKCHA, J.M.G.; BANDO, E. et al. Occurrence and antibiotic resistance of coliform bacteria and antimicrobial residues in pasteurized cow's milk from Brazil. J. Food Prot., v.73, p.1684-1687, 2010. 